\title{
Impact of Governments' Fiscal Behaviors on Public Finance Sustainability: A Comparative Study
}

\author{
Mihaela Onofrei ${ }^{1}$, Tudorel Toader ${ }^{2}$, Anca Florentina Vatamanu ${ }^{1}$ (D) and Florin Oprea ${ }^{1, *}$ \\ 1 Department of Finance, Money and Public Administration, Faculty of Economics and Business \\ Administration, Alexandru Ioan Cuza University, 700505 Iasi, Romania; onofrei@uaic.ro (M.O.); \\ gavriluta.anca@yahoo.com (A.F.V.) \\ 2 Faculty of Law, Alexandru Ioan Cuza University of Iasi, 700505 Iasi, Romania; ttoader@uaic.ro \\ * Correspondence: foprea@uaic.ro
}

check for updates

Citation: Onofrei, M.; Toader, T.; Vatamanu, A.F.; Oprea, F. Impact of Governments' Fiscal Behaviors on Public Finance Sustainability: A Comparative Study. Sustainability 2021, 13, 3739. https://doi.org/ $10.3390 /$ su13073739

Academic Editor: Donato Morea

Received: 16 February 2021

Accepted: 24 March 2021

Published: 27 March 2021

Publisher's Note: MDPI stays neutral with regard to jurisdictional claims in published maps and institutional affiliations.

Copyright: (c) 2021 by the authors. Licensee MDPI, Basel, Switzerland. This article is an open access article distributed under the terms and conditions of the Creative Commons Attribution (CC BY) license (https:/ / creativecommons.org/licenses/by/ $4.0 /)$.

\begin{abstract}
The aim of this research is to highlight the specificity of fiscal sustainability in some developing EU countries by analyzing the implications of fiscal rules on governments' fiscal behaviors. We employ a panel data analysis to evaluate developing EU countries for the period 2000-2014 and we investigate the status of convergence of fiscal responsibility coordinates by computing the convergence score of fiscal responsibility. The research is based on interdisciplinary coordinates and helps to consolidate judgments from both legal and financial perspectives, making a contribution to the literature that investigates the relationship between the legal framework related to government decision-making and public finance sustainability. The choice of the study sample in relation to developing EU countries represents a contribution and a point of reference for the literature that investigates the sustainability of developing EU countries and highlights the importance of fiscal risk management and control mechanisms in enhancing the performance of the public sector and fiscal sustainability. The results suggest that it is important to reinforce the interaction between the legal framework and the institutional one by identifying good practices for designing and operating effective independent fiscal institutions, making them capable not only of advising the government on fiscal policy matters but also of promoting sound fiscal policy and sustainable public finance.
\end{abstract}

Keywords: fiscal policies; public finance sustainability; fiscal rules; fiscal risk management; public sector performance

\section{Introduction}

In a perfect world of fully informed decision-makers, motivated exclusively by maximizing social welfare, fiscal diligence would allow them to respond optimally to changing circumstances at any time. In the real world, however, information asymmetries are ubiquitous, time inconsistencies are high, and political behavior is shaped by considerations other than pure social welfare. The need to pay special attention to the problem of fiscal discipline in many countries of the world has arisen with a series of questions regarding the implementation of the appropriate tools to control irresponsible fiscal policies, most often invoking variables such as the importance of numerical rules and fiscal councils, the implications of short- and long-term budgetary frameworks or the status of fiscal decentralization [1-3]. Indeed, researchers highlight that fiscal rules are an important part of EU commitment devices to influence governments' behaviors towards fiscal discipline, stability, and transparency [4-6]. Viewed as an insurance base for fiscal sustainability, fiscal rules were introduced as a tool for empowering the political decision-makers and to ensure an institutional safeguard against cross-border spillovers of national unsustainable fiscal policies.

Discretionary fiscal-budgetary policies suffer from two major shortcomings that are interdependent. First, there is a propensity for growing budget deficits and procyclicality. Second, a budget deficit involves higher public spending than revenue, and procyclicality 
involves fiscal policy actions that amplify the phases of the economic cycle-for example, decreasing taxes in the boom or increasing them in periods of decline. Therefore, it is appropriate to recognize the implications of independent fiscal institutions capable of improving the budget-making process and to ensure a real process of fiscal consolidation. In combination with fiscal-budgetary rules (limitation of budget deficits and public debt), these new institutions are considered to strengthen budgetary discipline.

Despite the increased importance of the fiscal institutions and even if they have a status which is different from other governmental bodies, according to the OECD, independent fiscal institutions are entities financed by public funds, subordinate to the executive or legislative statistical authority, which ensures budget supervision and analysis and, in some circumstances, advice on the fiscal policy and fiscal enforcement. Thus, we admit that contrary to the opinions and early academic proposal study of Debrun and Kumar [7], independent fiscal institutions do not exercise their official authority over fiscal policies, their involvement being to consolidate the means of advice of transparency mechanisms and to make the public decision-makers responsible.

According to Bettsma and Debrun's [8] point of view, the entire fiscal governance framework started to develop after the global financial crisis of 2008, and it is shown that the increase in the number of fiscal councils is a recent phenomenon. It is also revealed that the time of crises causes profound changes in existing legislation and can lead to the requirement of new fiscal consolidation mechanisms. The only exceptions from this point of view are countries such as the United States (1974), Austria (1970), or the Netherlands (1945).

The interest in strengthening the status of fiscal councils to consolidate the entire European fiscal governance framework is based on well-known fiscal sustainability desires and the achievement of the objective of pursuing sound policies. However, even if the consolidation of public finance is globally sustained, most of the existing fiscal institutions identified by the International Monetary Fund (IMF) at the end of 2016 were in the EU. Therefore, assuming that fiscal councils have been set up relatively recently in most EU countries, there are considerable variations between different countries and it is difficult to establish the exact implications of fiscal policy or to evaluate the status at this stage, with it only being possible to decide on their impact on EU fiscal strategies. Fiscal rules can be extremely useful, but their effectiveness and the impact on reducing the procyclicality of fiscal policy depends on government efficiency, meaning that the assessment of the effectiveness of fiscal rules is related to government fiscal behavior and the fiscal consolidation process depends on fiscal conservatism and the government's interest in promoting sound fiscal policies.

After 2011, the increase in the number of fiscal councils in Europe is due to the Directive on the requirements for budgetary frameworks in the Member States and the intervention of the so-called TwoPack legislative package, together with the provisions of the Treaty on Stability, Coordination and Governance in the Economic and Monetary Union, including the Fiscal Compact, which in 2013 established the need to create "independent fiscal institutions" in the euro area countries. Additionally, 2013 saw the end of the sovereign debt crisis in Europe and the entire governance framework started to be linked to fiscal surveillance framework and numerical fiscal rules [9-11]. In the context of discussions on the mandate of fiscal institutions, specific tasks, and attributions, we admit that they vary greatly between countries, relating very much to the ideology of budgetary processes, history and political customs. However, the final objective is the same-namely, to provide objective information and appropriate incentives to decision-makers and all the actors involved in the process of public finances management. Regarding the essence of the approach to this subject, respectively, and the extent to which we can discuss the efficiency of these institutional bodies, we could say that although they do not have the power to control any fiscal leverage, due to the impact on public finance prognoses and based on the fact that fiscal institutions can reveal public policy deviations from the established fiscal arrangements, fiscal transparency can be increased and encourage governments to 
comply with the rules. As far as we are concerned, although the literature shows that fiscal institutions (fiscal councils) do not have representative channels through which to influence the results of fiscal policy [12-14], we consider the status of independent fiscal councils as insufficiently substantiated within the limits of a legal framework capable of holding decision-makers accountable, not hiding political mistakes, and imposing reputational costs on unsustainable policies. Many governments do not have basic information on the range and potential of the increased fiscal risks to which they are exposed [15]. In many countries, public institutions do not have sufficient information or capabilities to provide comprehensive, relevant, and timely reporting of public finance risks, and institutional mechanisms are also problematic. Therefore, we may argue that even if fiscal rules and the entire European fiscal framework are beneficial to sound public finances, in the absence of fiscal policy coordination, and due to the inability to follow the national or European fiscal targets, the government's fiscal behavior can be incapable of achieving sustainable public finances, even more so in developing countries that need solid fiscal consolidation frameworks.

The objective of this paper is to employ a panel data analysis for the developing EU countries for the period 2000-2014 and to investigate the status of convergence of fiscal responsibility coordinates by computing the convergence score of fiscal responsibility. The idea of the research is based on interdisciplinary coordinates and helps to consolidate judgments from both legal and financial perspectives, making a contribution to the literature that investigates the relationship between the legal framework related to government decision-making and public finance sustainability.

The contribution to the existing literature is emphasized by the integration in the empirical analysis of both a set of fiscal attitude variables and government fiscal consolidation measures and by a computed convergence score of fiscal responsibility. Fiscal rule variables represent the novelty of our study since, unlike other studies, we include the fiscal rule straight index (FRLS_index)—-the well-known indicator provided by the IMF-and the results of a qualitative analysis (Converg_FRL), which captures the specificity of the numerical fiscal rules of both legal and institutional frameworks. More precisely, considering the particularities of each country on this topic, we resorted to creating a convergence score that considers all the coordinates of fiscal rules from developing EU countries. The choice of the study sample in relation to developing EU countries represents a contribution and a point of reference for the literature that investigates the sustainability of developing EU countries and highlights the importance of fiscal risk management and control mechanisms in enhancing the performance of the public sector and fiscal sustainability. The list of the examined countries includes Bulgaria, Croatia, Czech Republic, Estonia, Hungary, Latvia, Lithuania, Poland, Romania, Slovakia and Slovenia. The remainder of the paper is structured as follows: in Section 2 we highlight the theoretical background linked to the specific topic, in Section 3 we describe the methodology used; in Section 4 we discuss the empirical findings and sustainability assessments; Section 5 provides the conclusions.

\section{Literature Review}

The status of fiscal sustainability and the analysis of impacts of fiscal rules on governments' fiscal behaviors in EU countries represent subjects of research in academic articles that researchers have tackled for years, endeavoring to shape the contribution of fiscal mechanisms and entire fiscal governance framework to be more sustainable in terms of of public finances. For instance, according to insights in the literature, it is highlighted that the introduction of fiscal rules is correlated with better fiscal performance and some empirical studies note that countries that adopt fiscal rules tend to have better fiscal outcomes, including running smaller fiscal deficits [16-19]. Similar views have been previously presented, such as by Krogstrup and Wälti [20], who argued that fiscal rules continue to have a significant impact on real budget balances. In line with the above, Wyplosz [21] highlighted a direct implicationof independent and accountable fiscal policies on debt targets and following the theoretical insights related by Wierts [22], it was found that the 
institutional design of the rules follows political willingness to adopt different levels of GDP ratios and a straight rule can restrain the impact on expenditure outcomes. Later on, Wyplosz [23] pointed out four important dimensions of fiscal rules: the vulnerability of rules to time inconsistency, followed by escape clauses; the cost of population aging, which involves higher health costs; the financial favors for interest groups, which based on voters support can lead to deficit bias when the level of taxation becomes a problem; and finally, the reverse causality of rules-namely, that fiscal consolidation processes depend on governments' discipline and each country's conservatism. Thus, it should be noted that in the process of consolidating the fiscal-budgetary responsibility, both the political and the institutional aspects are extremely important. In reference to the concept of fiscal illusion, in which voters do not understand the implications of intertemporal constraints and therefore do not approve of unsustainable fiscal policies, we could say that public debt is a strategic variable used by governments to deepen the intergenerational burden but also to constrain the actions of future governments.

Due to fiscal performance deterioration, there are many debates about the direction that fiscal policy should take and what the appropriate instruments are for responsible governments. On the one hand, due to economic turmoil and unsustainable decisions, public debt stocks are higher than ever, requiring a long-term fiscal adjustment. On the other hand, the presence of doubts about the effectiveness of fiscal rules and political costs tends to slow fiscal consolidation and provide short-term incentives. It is not clear which is the "right" way to achieve fiscal consolidation and there are missing variables that are needed to balance these considerations. Additionally, the balance, of course, can be different depending on the specific situation of each country. The status of autonomous spending and the tendency to run excessive deficits imply a deterioration in the budget process and affect the future of the next generation, who should support higher taxes. Fiscal-budgetary responsibility has been and will continue to be a topic of interest in the developing European Union countries, which is why it is also the subject matter of this research. Following the insights in the literature, Bova et al. [24] analyzed the status of fiscal rules in the developing countries and found that fiscal policy remains procyclical when succeeding in the adoption of fiscal rules, and a powerful legal framework could be associated with lower procyclicality. Reuter, W.H. [25] investigates the effects of (non)compliance with national numerical fiscal rules on fiscal policy in $11 \mathrm{EU}$ member states over the period 1994 to 2012 and reveals that the introduction of fiscal rules does significantly change the behavior regarding fiscal policy. Bergman et al. [26] argued that even if fiscal rules and the entire fiscal governance mechanisms are effective in improving government efficiency and reduce structural deficits, the effect depends on the institutional background and the method of enhancing fiscal solvency implies multiple rules. In line with the above, Calmfors [27] points out that fiscal councils, seen as independent fiscal watchdogs, are particularly important in strengthening fiscal discipline because they can establish the reputational costs for policy-makers who violate the rules [28], and conducted an analysis of fiscal rules on the profiles of 81 countries around the world and emphasized some characteristics of fiscal rules-e.g., the fact that numerical rules represent the response to the crisis, the design features in emerging economies have caught up with those in advanced economies and the next generation fiscal rules require new challenges to ensure effectiveness and long-term sustainability.

Weak fiscal discipline and occasional catastrophic losses of fiscal control are too frequent, especially in developing countries. The growing interest in fiscal rules and policy in the past two decades reveals the efforts to consolidate public finance sustainability and reduce public sector debts by approaching numerical targets. However, while fiscal rules seem appropriate to limit the government borrowing and to target the deficit, the improvement in a government's fiscal balance can be possible without an appropriate institutional design capable of making the budget process effective. By addressing these issues, some studies have concluded that fiscal rules have a positive impact on fiscal outcomes, particularly in countries that make large adjustments in revenue or spending 
policies and given that they are time-inconsistent by default, the effectiveness and direct positive impact on fiscal consolidation are dictated by the institutions [21,29]. Additionally, following the most recent literature insights, the implications of institutional determinants of budgetary expenditures are also recognized, as well as the status of the common fiscal framework [30].

The insights in the literature reveal that in order to achieve a prudential execution of the budget and to establish feasible strategic directions for the correct management of public finance mechanisms, the issue of regulations in the field of public finance is increasing, with an emphasis on fiscal responsibility dimensions. In this way, it intervenes with the focus on the nature of accountability of authorizing officers and implicitly with the establishment of institutional mechanisms meant to ensure the smooth running of the economy and the accountability of policy-makers at all levels. Fiscal institutions are at the core of assessing fiscal sustainability, and the significance of institutions in terms of pointing out the differences in fiscal outcomes among countries is revealed by certain insights in the literature which highlight that fiscal attributes and structural implementation, the budget process, and the political system, as well as policy rules and procedural rules, are likely to influence fiscal performance $[19,22,31,32]$. As long as fiscal rules and transparency promote better budget balances, domestic political actors can use fiscal institutions to constrain executive policy-making and achieve public finance sustainability.

In accordance with the research objective, we can see from the emphasis on the specificity of fiscal sustainability in some developing EU countries and the analysis of the impact of fiscal rules on governments' fiscal behaviors that fiscal rules incorporating institutional status and the implications of creating a legal basis for these rules have not been analyzed. Instead, numerical fiscal rules, as the main policy tool seems to be even more important for developing countries [33]. When retrospectively analyzing previous research focused on developing countries, it was confirmed on one hand that there was evidence of the cyclical behavior of fiscal policy as well as a prevalence of procyclical behavior [34]. On the other hand, the insights in the literature reveal that fiscal rules do improve fiscal discipline in developing countries, with the observation that the disciplineenhancing effect of fiscal rules varies with the types of rules and also depending on the countries' structural characteristics [35]. Additionally, Bova et al. [24]. focus on the socalled second generation fiscal rules and find that those rules have contributed to reducing spending procyclicality in developing countries, while based on Drazen's [36] point of view, the implication of fiscal manipulation before elections is highlighted, clearly indicating that fiscal manipulation is especially strong in developing countries and the level of spending is guided by political stakes.

The practical way to determine the effectiveness of fiscal rules in consolidating public finances and maintaining macroeconomic stability depends on the fiscal conservatism and a government's capability of establishing a debt ceiling or target and to ensure access to finance in time of crisis. In line with this, the literature validates the fact that in times of recession, a fiscal rule leads financial markets to reduce the risk [37] and sound implementation of fiscal rules is an instrument for policy-makers to improve developing countries' financial market access [38].

This research captures the time inconsistency problem by assessing the compliance with the principles of fiscal governance through a panel data analysis for developing EU countries for the period 2000-2014 and investigates the status of convergence of fiscal responsibility coordinates through the computation of convergence scores of fiscal responsibility.

\section{Empirical Framework and Methodology}

The aim of this study is to highlight the status of fiscal sustainability in some developing EU countries by analyzing the implications of fiscal rules on governments' fiscal behaviors. We employed a panel data analysis of developing EU countries for the period 2000-2014 and we investigated the status of convergence of fiscal responsibility coordinates by computing the convergence score of fiscal responsibility. The choice of the study sample, 
i.e., using developing EU countries, represents a contribution and a point of reference for the literature that investigates the sustainability of developing EU countries and highlights the importance of fiscal management tools and control mechanisms in enhancing the performance of the public sector and fiscal sustainability. Thus, the key element in consolidating and achieving fiscal sustainability is represented by the analysis of the current institutional fiscal policy framework. With respect to this, according to the IMF, the rate of compliance with fiscal rules by groups of countries indicates a greater preference for the profile of emerging countries for debt rules, which is explained not only by financial difficulties and political instability in these countries, but also by large budget deficits, which necessitates the improvement of the quality of public spending. However, under the auspices of this settlement, it can be clearly judged that based on the profile of emerging countries, the low level of compliance with the rules on expenditure raises a first question mark regarding the effectiveness of the substantiation of the fiscal-budgetary strategy.

The extreme coercion options, in case of noncompliance, are suboptimal and lead to low credibility in most Member States. Most countries violate the rules set by the Stability and Growth Pact (SGP), either due to a lack of viable forms of accountability and coercion or due to legislative flaws that allow irresponsible behavior. A decisive stimulant to increase the independence of a fiscal organization has been provided by the evolution of legislative framework at EU level, in which the new requirements for the status, tasks and functions of these structures were enshrined in legislation. More specifically, the entire fiscal governance framework has started to be related to the idea of fiscal transparency, which is followed by more detailed and prescriptive provisions.

Following the requirements stipulated in Directive 2011/85/EU, adopted in November 2011 as part of the so-called "Six-pack" legislation on economic governance, new options are revealed to manage the status of the national budgetary framework, this being linked to the necessity to consolidate the status of fiscal institutions by considering the strengths of independent fiscal authorities. Directive 2011/85/EU, adopted in November 2011 as part of the so-called "Six-pack" legislation on economic governance, already contains a reference to the need to strengthen independent bodies. First, national fiscal rules should be related to compliance with EU-wide fiscal rules, acting as the first line of defense against breaches of the EU fiscal rules. Secondly, in accordance with Article 6, numerical rules within the meaning of the directive should be equipped with procedures to ensure "effective monitoring and timely compliance with the rule". In view of the analysis, the long-term fiscal sustainability challenges facing EU countries were found to be deepening and there is not yet a concrete picture regarding fiscal responsibility conditions and the convergence of defined legal requirements. Thus, following the theoretical insights proposed by Blanchard et al. and Bohn [39,40] for empirical tests of sustainability frameworks, we analyzed the primary fiscal balance in relation to debt levels, which can be written as follows:

$$
p b_{t}=\mathrm{k} \cdot g_{t}+\xi_{t},
$$

where $p b_{t}$ represents primary balance in relation to GDP, $g_{t}$ indicates government debt to GDP ratio, $\mathrm{k}$ indicates the reaction of the primary balance to the debt ratio and $\xi_{t}$, comprises effects of institutional and economic determinants of primary balance. According to Bohn [40], the intertemporal budget conditions can be satisfied only if the economic conjuncture follows the so-called Ponzi condition, in which case $\kappa>0$ is adequately provided and the present value of GDP is finite and $\xi_{t}<\infty$, as a fraction of GDP. However, based on recent insights in the literature [41-43], it is highlighted that even if $\mathrm{k}$ is positive, it is not sufficient to achieve fiscal consolidation and public finance sustainability if it can be a limit for positive values of primary balance at high debt levels or if we talk about the implications of financial markets and interest rate growth. Therefore, our empirical strategy follows Afonso and Jalles and Afonso and Hauptmeier [44,45], and based on the 
fiscal reaction function, we test the reaction of budget balance at the public debt level, also analyzing the implication of the fiscal convergence position:

$$
P b_{i t}=\beta_{i}+\delta P b_{i t-1}+\theta g_{i t-1}+\lambda \mathrm{O}_{i t-1}+\varnothing f_{i t}+\gamma x_{i t}+\alpha t+u_{i t}
$$

where $\beta_{i}$ indicates the model parameters, $P b_{i t}$ represents the government net borrowing or net lending, excluding interest payments on consolidated government liabilities (named primary balance \% GDP) for country $i$ in period $\mathrm{t}, \mathrm{P} b_{i t-1}$ is the same variable observation for country $i$ in the last period $(t-1)$, and $g_{i t-1}$ represents public debt as \% GDP in period $\mathrm{t}-1$ for country $i$. O indicates the GDP gap, which is the actual GDP minus the potential GDP and divided by the potential GDP, while the variable was computed based on the Hodrick-Prescott filter, f represents the status of fiscal convergence and includes the separate fiscal rule straight index (FRLS_index) and the context of convergence of fiscal rules (Converg_FRL), computed based on the judgment highlighted in Appendix A. $x$ is a vector which integrates the dummy variable of the financial crisis (which represents a time period of precrisis, crisis and postcrisis). Additionally, $u_{i t}$ errors are presumed to be independent, and the model includes time fixed effects.

In other to analyze the implication of debt indebtedness and to verify if fiscal rules can be effective at different debt levels, we have introduced interaction terms between public debt as \% GDP and different debt thresholds $(50,70,90)$ and we computed a dummy threshold variable:

$D_{i t}^{T H}=1$, if debt ratio $>T H$, in country $i$ in period $t, 0$, otherwise. $T H=0.5,0.7,0.9$

Finally, given that the way to fiscal consolidation involves a direct implication on diligence in spending measures, we also tested the status of primary expenditure by using the primary spending reaction function (Equation (4)).

$$
p e_{i t}=w_{i}+w_{1} p e_{i t-1}+w_{2} g_{i t-1}+w_{3} O_{i t-1}+w_{4} f_{i t}+w_{5} x_{i t}+w_{6} t+v_{i t}
$$

where $p e_{i t}$ is a measure of the primary spending-to-GDP ratio for country $i$ in period $t$, $p e_{i t-1}$ is the same variable, i.e., primary spending-to-GDP ratio for country $i$ in period $\mathrm{t}-1$, and some additional variables, which are similar to those stipulated in Equation (3). The entire econometric approach tests the government's reaction in terms of fiscal strategies and accountability when the debt levels increase. Thus, one of the methods to solve this is to look for government reactions to public debt levels, expecting, based on consolidation premises, to ensure the government solvency, and primary balance reacts to the different debt levels. At the same time, we expect that straight fiscal rules have a positive influence on the primary balance and on the government's behavior in terms of spending.

Given that our panel study is based on developing EU countries and the units in the panel are small (14 years and 11 countries), in order to solve the econometric issues of the panel data framework, we used the vcov function and, based on insights in the literature [46], the Least Square Dummy Variable (LSDV) estimator, which is appropriate for unbalanced panels. The results are presented in Section 3 of our study.

\section{Results and Discussion}

As far as our research investigates the government's fiscal behavior impact on public finance sustainability in developing EU countries, we employed a panel data analysis and we investigated the status of fiscal responsibility, also highlighting the convergence of fiscal responsibility coordinates by computing the convergence score of fiscal responsibility. The idea of the research is based on interdisciplinary coordinates and helps to consolidate judgments from both legal and financial perspectives, making a contribution to the literature that investigates the relationship between the legal framework related to government decision-making and public finance sustainability. The variables employed in the panel data analysis were retrieved from the European Commission's AMECO database, the International Monetary Fund (IMF) database. Following insights in the literature [47], 
the panel unit root test results are reported in Appendix B and indicate the stationarity of the dependent variables used in the analysis. An F-test validated the assumed fixed effects and the test for heteroscedasticity (named Wald test) highlighted the utility of fixed effect regression models. The Ordinary Least Squares (OLS) regression results are reported in the following paragraphs, Table 1 reveals the estimation results for fiscal reaction functions in line with primary balance and Table 2 indicates the implication of primary expenditure and the responses of primary balances at different levels of indebtedness.

Table 1. Fiscal reaction function estimation results (dependent variable: primary balance, period 2000-2014).

\begin{tabular}{|c|c|c|c|}
\hline Variable & FRLS_index (Equation (2)) & Converg_FRL (Equation (2)) & LSDV $^{1}$ DUMMY Crisis \\
\hline Primary balance $(-1)$ & $\begin{array}{l}0.083 \\
(1.70)\end{array}$ & $\begin{array}{l}0.081 \\
(1.60)\end{array}$ & $\begin{array}{c}0.180 \\
(3.61)^{* *}\end{array}$ \\
\hline Public debt \% GDP $(-1)$ & $\begin{array}{c}-0.150 \\
(14.93) * *\end{array}$ & $\begin{array}{c}-0.152 \\
(15.02) * *\end{array}$ & $\begin{array}{c}-0.198 \\
(13.08)^{* *}\end{array}$ \\
\hline Output Gap (-1) & $\begin{array}{c}0.152 \\
(3.33)^{* *}\end{array}$ & $\begin{array}{c}0.150 \\
(3.18)^{* *}\end{array}$ & $\begin{array}{c}0.159 \\
(3.35)^{* *}\end{array}$ \\
\hline FRLS_index & $\begin{array}{c}0.781 \\
(3.78) * *\end{array}$ & & $\begin{array}{c}0.888 \\
(3.23)^{* *}\end{array}$ \\
\hline Converg_FRL & & $\begin{array}{c}-0.028 \\
(0.06) \\
\end{array}$ & $\begin{array}{l}0.277 \\
(0.57) \\
\end{array}$ \\
\hline Crisis dummy & & & $\begin{array}{l}-2.697 \\
(3.37)^{* *}\end{array}$ \\
\hline Adjusted R2 & 0.5755 & 0.5490 & 0.6431 \\
\hline F-test & 7.11 & 5.65 & \\
\hline Wald test & & & $\begin{array}{l}317.64 \\
0.0000\end{array}$ \\
\hline
\end{tabular}

${ }^{1}$ The Least Square Dummy Variable (LSDV) estimator suggested by Bruno (2005) [33]. Dummy integrates the xtreg function associated with OLS panel data. Note: the results include the coefficient of variable and ${ }^{*}$ statistic results in parentheses ${ }^{* *} p<0.05$.

The results provided in Table 1 highlight the fact that primary balance reaction to government debt levels is negative and statistically significant, showing that governments from developing EU countries do not promote fiscal behavior, which is in accordance with the fiscal framework requirements and related to the existing stock of government debt. It seems that fiscal policy did not react in accordance with fiscal consolidation mechanisms, implementing correcting measures to counteract such a trend and to solve the policy challenges facing developing countries.

Certainly, the globalization and changing international environment in terms of taxation and fiscal policy strategies have affected the status of developing countries and the fact that they do not react in accordance with debt levels indicates the implication of procyclical fiscal policy, confirming the theoretical insights of Bergman and Hutchison and Eyraud et al. [48,49]. On the other hand, according to the literature, it is shown that the main objective of fiscal rules is to reduce political deficit bias and facilitate long-term sustainability $[19,26,50-53]$, this being confirmed by our results which suggest that strong fiscal rules positively affect primary balance. Instead, FRL convergence does not impact the primary balance because it does not reflect the respect for fiscal rules, but only the status of rules. This validates the assertion that when we exclusively test the presence of fiscal rules in place, the analysis can be biased, because the structural characteristics and institutional variables of countries are missing.

Concerning the implication of the global financial crisis of 2008, it is highlighted that the fiscal space may become larger and can guide policy decision-makers to unsustainable fiscal policies, while stronger fiscal rules can improve the status of primary balance and penalize based on the political stakes behind public management processes. In the current context, given the challenges imposed by an aging population, the level of public debt 
could become higher, and the entire fiscal governance framework could be inconsistent or, more exactly, could deepen the risks of inconsistency and overlap, preventing the exercise of sustainable public finances. Therefore, in terms of fiscal governance and institutional implications, we find that the effective implementation of numerical rules and respect of them depends on fiscal attitude, fiscal conservatism, and public performance indicators and even if fiscal institutions are funded independent of the government, the optimal design of a rules-based fiscal framework varies from country to country.

Table 2. Fiscal reaction function estimation results (dependent variable: primary balance with the implication of debt thresholds and primary spending, period 2000-2014).

\begin{tabular}{|c|c|c|c|c|c|c|}
\hline Variable & 3 & 3 & $3^{*}$ & $4^{*}$ & $4^{* *}$ & $4^{* *}$ \\
\hline Primary spending $(-1)$ & & & & $\begin{array}{c}-0.021 \\
(0.18)\end{array}$ & $\begin{array}{c}-0.018 \\
(0.16)\end{array}$ & $\begin{array}{c}-0.039 \\
(0.34)\end{array}$ \\
\hline Primary balance $(-1)$ & $\begin{array}{c}0.145 \\
(2.86)^{* *}\end{array}$ & $\begin{array}{c}0.147 \\
(2.97)^{* *}\end{array}$ & $\begin{array}{c}0.139 \\
(2.68) * *\end{array}$ & & & \\
\hline Public debt \% GDP $(-1)$ & $\begin{array}{c}-0.171 \\
(11.38)^{* *}\end{array}$ & $\begin{array}{c}-0.168 \\
(14.68)^{* *}\end{array}$ & $\begin{array}{c}-0.140 \\
(14.39)^{* *}\end{array}$ & $\begin{array}{c}-0.067 \\
(1.93)\end{array}$ & $\begin{array}{c}-0.068 \\
(1.94)\end{array}$ & $\begin{array}{l}-0.067 \\
(1.97)\end{array}$ \\
\hline Output Gap & $\begin{array}{c}0.167 \\
(3.50)^{* *}\end{array}$ & $\begin{array}{c}0.160 \\
(3.43)^{* *}\end{array}$ & $\begin{array}{c}0.183 \\
(3.72)^{* *}\end{array}$ & $\begin{array}{c}-0.155 \\
(1.31)\end{array}$ & $\begin{array}{c}-0.172 \\
(1.42)\end{array}$ & $\begin{array}{c}-0.050 \\
(0.42)\end{array}$ \\
\hline FRLS_index & $\begin{array}{c}1.178 \\
(4.18)^{* *}\end{array}$ & $\begin{array}{c}1.162 \\
(4.27)^{* *}\end{array}$ & $\begin{array}{c}1.156 \\
(4.01)^{* *}\end{array}$ & $\begin{array}{c}-1.831 \\
(2.58)^{* *}\end{array}$ & $\begin{array}{l}-1.829 \\
(2.57) *\end{array}$ & $\begin{array}{l}-1.701 \\
(2.46)\end{array}$ \\
\hline Converg_FRL & $\begin{array}{c}0.192 \\
(0.42)^{* *}\end{array}$ & $\begin{array}{c}0.134 \\
(0.30)^{* *}\end{array}$ & $\begin{array}{l}0.272 \\
(0.57) \\
\end{array}$ & $\begin{array}{c}3.197 \\
(2.62)^{* *}\end{array}$ & $\begin{array}{c}3.214 \\
(2.62)^{* *}\end{array}$ & $\begin{array}{l}1.344 \\
(1.00)\end{array}$ \\
\hline Election cycle dummy & & & & & $\begin{array}{l}0.734 \\
(0.72) \\
\end{array}$ & \\
\hline Crisis & & & & & & $\begin{array}{c}3.194 \\
(2.94)^{* *}\end{array}$ \\
\hline D50 $(-1) \times \operatorname{Debt}(-1)[a]$ & $\begin{array}{c}-7.089 \\
(3.13)^{* *}\end{array}$ & & & & & \\
\hline$(1-\operatorname{D50}(-1)) \times \operatorname{Debt}(-1)[b]$ & $\begin{array}{c}0.132 \\
(3.60)^{* *}\end{array}$ & & & & & \\
\hline D70 $(-1) \times \operatorname{Debt}(-1)[c]$ & & $\begin{array}{c}-15.381 \\
(1.54) \\
\end{array}$ & & & & \\
\hline$(1-\operatorname{D} 70(-1)) \times \operatorname{Debt}(-1)[\mathrm{d}]$ & & $\begin{array}{l}0.241 \\
(1.87) \\
\end{array}$ & & & & \\
\hline D90 $(-1) \times \operatorname{Debt}(-1)[\mathrm{e}]$ & & & $\begin{array}{c}-5.021 \\
(2.23)^{* *}\end{array}$ & & & \\
\hline$(1-\mathrm{D} 90(-1)) \times \operatorname{Debt}(-1)[\mathrm{f}]$ & & & $\begin{array}{c}0.322 \\
(2.10)^{* *}\end{array}$ & & & \\
\hline Adjusted R2 & 0.590 & 0.5841 & 0.5528 & 0.4104 & 0.3404 & 0.3934 \\
\hline $\begin{array}{l}\text { Wald test (Wald chi2/Prob > } \\
\text { chi2) }\end{array}$ & $\begin{array}{l}282.24 \\
0.0000\end{array}$ & $\begin{array}{l}306.73 \\
0.0000\end{array}$ & $\begin{array}{l}256.68 \\
0.0000\end{array}$ & $\begin{array}{l}113.61 \\
0.0000\end{array}$ & $\begin{array}{l}1140.4 \\
0.0000\end{array}$ & $\begin{array}{c}22.99 \\
0.0008\end{array}$ \\
\hline
\end{tabular}

Note: the results include the coefficient of variable and ${ }^{*} t$ statistic results in parentheses. ${ }^{* *} p<0.05,{ }^{*} p<0.1 .3^{*}-$ The null hypothesis: $\mathrm{a}=\mathrm{b} ; \mathrm{c}=\mathrm{d} ; \mathrm{e}=\mathrm{f} .3-3^{*}$-The significance of the debt thresholds: Equations 3 and $4^{*}$-Primary spending reaction functions: Equation (4). $4^{* *}$-Primary spending reaction functions and implication of electoral cycle dummy. $4^{* *}$-Primary spending reaction functions and implication of crisis.

Moreover, the entire fiscal governance framework should require not only accountability in terms of respect of fiscal rules or transparency, but also a direct implication on the strategies related to spending, taxation, and the accepted level of public debt. Specifically, fiscal policy should follow an optimal rate of economic growth, which is why Table 2 
indicates the fiscal reaction function estimation results for primary spending and primary balance (in which case we consider the implication of debt thresholds).

Following the results provided in Table 2, it is possible to observe that at high debt levels, convergence of fiscal responsibility does not impact the primary balance levels, while stronger fiscal rules can improve primary balance. Resulting from the convergence of FRL, we tested only the status of the fiscal rules approach in developing EU countries and not the compliance with those rules, which would require a new methodological approach able to highlight not only the convergence of FRL but also the status of the administrative and institutional frameworks.

The analysis of the fiscal rule variables represents the novelty of our study by the fact that in contrast to the other research cited above, we included the fiscal rule straight index (FRLS_index - the well-known indicator provided by the International Monetary Fund) and the results of qualitative analysis (Converg_FRL), which capture the specificity of the numerical fiscal rules and the implications of the institutional framework. As can be seen in Appendix A, we examined the type of fiscal rule in place (ER-Expenditure Rule, RR-Revenue Rule, BBR-Budget balance Rule, DR-Debt Rule) and then we established the legal basis of said rule (constitutional legal basis, international treaty legal basis, common law legal basis, coalition agreement, political commitment). The regression results presented in Table 2 show that when we talk about the election period, the power of rules, measured by the FRL straight rule, can improve the primary balance, but in the crisis period, based on the need to comply with the requirements of debt financing, it seems that a simple convergence of fiscal governance principles it is not enough, and solid mechanisms capable of ensuring respect for these rules are required as well as adequate institutional frameworks. Converg_FRL is statistically significant when we considered the low level of debt thresholds, but at a high level, it seems that we need more than numerical fiscal rules, which are necessary to approach independent fiscal institutions capable of implementing appropriate tools to control irresponsible fiscal policy and to make public decision-makers responsible.

Based on the qualitative analyses displayed in Appendix A, it seems that the status of the independent fiscal councils is insufficiently based within the limits of a legal framework capable of ensuring the responsibility of the decision-makers, so as not to hide the political mistakes but to impose reputational costs for unsustainable policies. The legal status of the fiscal rules and the entire institutional framework are not implemented at the constitutional level in most of the developing EU systems (except Latvia which has a budget balance rule implemented at the constitutional level and Poland with DR implemented at the constitutional level), making their mission more difficult as guardians ensuring the enforcement of fiscal rules.

The legal status of the fiscal councils has not reached the constitutional level in all systems - see the Romanian case and the implication of the Constitutional Court of Romania in 2019 and 2020 [54,55]. The optimal design of a rule-based fiscal framework varies from country to country, depending on the objectives of fiscal policy and institutional capabilities, which impose a challenge for the countries in Europe and around the world, respectively, to identify ways to strengthen the sustainability of public finances with reference to the legislative and institutional frameworks that are available or better, which they choose to manage following fiscal morale and responsibility or following the political stakes. Even if the sustainability of fiscal policy has steady growth as its purpose, as well as the initiation of a viable macroeconomic itinerary, the emphasis falls on the longterm implications of, presumably, two primary variables: the demographic one (which considers the aging of the population) and the globalization, which through international competition will increase mobility and exposure to external shocks. Our contribution to the literature is threefold. First, we combined interdisciplinary coordinates and we consolidate judgments from both legal and financial perspectives, making a contribution to the literature that investigates the relationship between the legal framework related to government decision-making and public finance sustainability. Second, we analyzed 
the specificity of the numerical fiscal rules from both legal and institutional perspectives. Third, we contributed to the extant literature by providing additional insights on the status of fiscal sustainability in developing EU countries. Our results should draw attention for policy-makers from developing EU countries, who should accept the importance of fiscal risk management and control mechanisms in enhancing the performance of the public sector and fiscal sustainability and should consolidate the interaction between the legal framework and the institutional one.

\section{Conclusions}

The implications of the recent global financial crisis show the importance of identifying the source of vulnerabilities that impact and deepen the dimension of disasters and result in a negative range of economic effects. Fiscal rules appear as a key response to the fiscal legacy of the financial crisis and aim to consolidate fiscal mechanisms and the entire budgetary process by enhancing new mechanisms capable of ensuring sustainability of public finances. This research aims to highlight the status of fiscal sustainability in some developing EU countries by analyzing the implications of fiscal rules on governments' fiscal behaviors. Based on interdisciplinary coordinates, we conducted a panel data analysis of developing EU countries for the period 2000-2014 and investigated the status of convergence of fiscal responsibility coordinates by computing the convergence score of fiscal responsibility. The contribution to the existing literature is emphasized by the integration both of a set of fiscal attitude variables and government fiscal consolidation measures in the empirical analysis and by a computed convergence score of fiscal responsibility.

We demonstrate that it is important to consolidate the interaction between the legal framework and the institutional one by creating independent fiscal institutions capable of improving the budget-making process and to ensure a real process of fiscal consolidation. At this moment, we admit that fiscal institutions have a status that is different from other governmental bodies but in combination with fiscal-budgetary rules (limitation of budget deficits and public debt), these institutions should not only advise fiscal policy and fiscal enforcement, but should also strengthen budgetary discipline, ensuring budget supervision and analysis. The study results reveal that the fiscal balance reaction to government debt levels is negative and statistically significant, meaning that governments from developing EU countries do not perform in line with the existing stock of government debts.

When we talk about the necessity of handling the shock of a crisis, the results suggest that the fiscal space may become higher and can guide policy decision-makers to unsustainable fiscal policies, while a stronger fiscal rule can improve the status of primary balance and penalize based on the political stakes behind public management processes. The analytical framework provides some interesting insights in line with the election period, in which case it is revealed that the power of rules, measured by the FRL straight rule, can improve the primary balance, while during the crisis period, based on the need to comply with the requirement of debt financing, it seems that a simple convergence of the fiscal responsibility legal framework (Converg_FRL) is not enough; solid mechanisms capable of ensuring respect for these rules are required as well as an adequate institutional frameworks. With respect to the implications of the economic crisis, it is highlighted that the fiscal space may increase, setting out more scope for unsustainable fiscal policies, while a stronger fiscal rule in place can improve the status of the primary balance. The status of Converg_FRL is statistically significant when we talk about a low level of debt thresholds, but at high level, it seems that we need more than numerical fiscal rules, which are necessary to approach independent fiscal institutions capable of implementing appropriate tools to control irresponsible fiscal policies and make public decision-makers responsible. This rationale can be helpful for decision-makers, but also researchers, because it indicates that when we only test the presence of the fiscal rules in place, the analysis can be biased because the structural characteristics and institutional variables of the countries are missing.

As for the implications of the institutional elements, the judgments converge on the idea that in the absence of fiscal monitoring bodies that are politically independent, it is 
almost impossible to discuss the efficiency of budgetary institutions, including specific procedures for budget formulation, approval, and implementation.

Author Contributions: Conceptualization, M.O. and T.T.; methodology, F.O.; software, A.F.V.; validation, T.T., A.F.V. and M.O.; formal analysis, F.O.; investigation, T.T.; resources, M.O., T.T., F.O. and A.F.V.; data curation, A.F.V.; writing—original draft preparation, F.O.; writing-review and editing, M.O., T.T., A.F.V. and F.O. All authors read and approved the final manuscript. All authors have read and agreed to the published version of the manuscript.

Funding: This research received no external funding.

Institutional Review Board Statement: Not applicable.

Informed Consent Statement: Not applicable.

Data Availability Statement: Publicly available datasets were analyzed in this study. This data can be found here: AMECO database I European Commission (europa.eu); IMF Data.

Acknowledgments: For Florin OPREA (Faculty of Economics and Business Administration and Centre for European Studies-“'Alexandru Ioan Cuza" University of Iasi, Romania), this work was supported by a grant of Ministry of Research and Innovation, CNCS-UEFISCDI, project number PN-III-P4-ID-PCCF-2016-0166, within PNCDI III, project ReGrowEU-Advancing ground-breaking research in regional growth and development theories, through a resilience approach towards a convergent, balanced and sustainable European Union.

Conflicts of Interest: The authors declare no conflict of interest.

\section{Appendix A. The Results of Convergence Score of Fiscal Responsibility}

Table A1. Type of Fiscal Rule in Place and Legal Basis.

\begin{tabular}{|c|c|c|c|c|c|c|c|c|c|c|}
\hline \multirow{2}{*}{ Year } & \multirow{2}{*}{ Country } & \multicolumn{8}{|c|}{ Type of Fiscal Rule in Place and Legal Basis } & \multirow{2}{*}{$\begin{array}{c}\text { Convergence Score of Fisca } \\
\text { Responsibility } \\
\text { (Converg_FRL) }\end{array}$} \\
\hline & & ER & RR & BBR & DR & ERLB & RRLB & BBRLB & DRLB & \\
\hline 2010 & BG & 0 & 0 & 0.25 & 0.3 & 0 & 0 & 0.1 & 0.3 & 0.95 \\
\hline 2011 & BG & 0 & 0 & 0.25 & 0.3 & 0 & 0 & 0.1 & 0.3 & 0.95 \\
\hline 2012 & BG & 0.3 & 0 & 0.25 & 0.3 & 0.3 & 0 & 0.3 & 0.3 & 1.75 \\
\hline 2013 & BG & 0.3 & 0 & 0.25 & 0.3 & 0.3 & 0 & 0.3 & 0.3 & 1.75 \\
\hline 2014 & BG & 0.3 & 0 & 0.25 & 0.3 & 0.3 & 0 & 0.3 & 0.3 & 1.75 \\
\hline 2010 & $\mathrm{CZ}$ & 0 & 0 & 0.25 & 0.3 & 0 & 0 & 0 & 0 & 0.55 \\
\hline 2011 & $\mathrm{CZ}$ & 0 & 0 & 0.25 & 0.3 & 0 & 0 & 0 & 0 & 0.55 \\
\hline 2012 & $\mathrm{CZ}$ & 0.3 & 0 & 0.25 & 0.3 & 0 & 0 & 0 & 0 & 0.85 \\
\hline 2013 & $\mathrm{CZ}$ & 0.3 & 0 & 0.25 & 0.3 & 0 & 0 & 0 & 0 & 0.85 \\
\hline 2014 & $\mathrm{CZ}$ & 0.3 & 0 & 0.25 & 0.3 & 0 & 0 & 0 & 0 & 0.85 \\
\hline 2010 & HR & 0 & 0 & 0 & 0.3 & 0 & 0 & 0 & 0.3 & 0.6 \\
\hline 2011 & HR & 0 & 0 & 0 & 0.3 & 0 & 0 & 0 & 0.3 & 0.6 \\
\hline 2012 & HR & 0.3 & 0 & 0.25 & 0.3 & 0.3 & 0 & 0.3 & 0.3 & 1.75 \\
\hline 2013 & HR & 0.3 & 0 & 0.25 & 0.3 & 0.3 & 0 & 0.3 & 0.3 & 1.75 \\
\hline 2014 & HR & 0.3 & 0 & 0.25 & 0.3 & 0.3 & 0 & 0.3 & 0.3 & 1.75 \\
\hline 2010 & $\mathrm{EE}$ & 0 & 0 & 0.25 & 0.3 & 0 & 0 & 0.2 & 0 & 0.75 \\
\hline 2011 & $\mathrm{EE}$ & 0 & 0 & 0.25 & 0.3 & 0 & 0 & 0.2 & 0 & 0.75 \\
\hline 2012 & $\mathrm{EE}$ & 0.3 & 0 & 0.25 & 0.3 & 0 & 0 & 0.2 & 0 & 1.05 \\
\hline 2013 & $\mathrm{EE}$ & 0.3 & 0 & 0.25 & 0.3 & 0 & 0 & 0.2 & 0 & 1.05 \\
\hline 2014 & $\mathrm{EE}$ & 0.3 & 0 & 0.25 & 0.3 & 0 & 0 & 0.2 & 0 & 1.05 \\
\hline 2010 & LV & 0 & 0 & 0.25 & 0.3 & 0 & 0 & 0 & 0 & 0.55 \\
\hline 2011 & LV & 0 & 0 & 0.25 & 0.3 & 0 & 0 & 0 & 0 & 0.55 \\
\hline 2012 & LV & 0.3 & 0 & 0.25 & 0.3 & 0 & 0 & 0 & 0 & 0.85 \\
\hline
\end{tabular}


Table A1. Cont.

\begin{tabular}{|c|c|c|c|c|c|c|c|c|c|c|}
\hline \multirow{2}{*}{ Year } & \multirow{2}{*}{ Country } & \multicolumn{8}{|c|}{ Type of Fiscal Rule in Place and Legal Basis } & \multirow{2}{*}{$\begin{array}{c}\text { Convergence Score of Fisca } \\
\text { Responsibility } \\
\text { (Converg_FRL) }\end{array}$} \\
\hline & & ER & RR & BBR & DR & ERLB & RRLB & BBRLB & DRLB & \\
\hline 2013 & $\mathrm{LV}$ & 0.3 & 0 & 0.25 & 0.3 & 0 & 0 & 0.5 & 0.3 & 1.65 \\
\hline 2014 & LV & 0.3 & 0 & 0.25 & 0.3 & 0.3 & 0 & 0.5 & 0.3 & 1.95 \\
\hline 2010 & LT & 0.3 & 0.25 & 0.25 & 0.3 & 0.3 & 0.3 & 0 & 0.3 & 2 \\
\hline 2011 & LT & 0.3 & 0.25 & 0.25 & 0.3 & 0.3 & 0.3 & 0 & 0.3 & 2 \\
\hline 2012 & LT & 0.3 & 0.25 & 0.25 & 0.3 & 0.3 & 0.3 & 0 & 0.3 & 2 \\
\hline 2013 & LT & 0.3 & 0.25 & 0.25 & 0.3 & 0.3 & 0.3 & 0 & 0.3 & 2 \\
\hline 2014 & LT & 0.3 & 0.25 & 0.25 & 0.3 & 0.3 & 0.3 & 0 & 0.3 & 2 \\
\hline 2010 & PL & 0 & 0 & 0.25 & 0.3 & 0 & 0 & 0 & 0.5 & 1.05 \\
\hline 2011 & PL & 0.3 & 0 & 0.25 & 0.3 & 0.3 & 0 & 0 & 0.5 & 1.65 \\
\hline 2012 & PL & 0.3 & 0 & 0.25 & 0.3 & 0.3 & 0 & 0 & 0.5 & 1.65 \\
\hline 2013 & PL & 0.3 & 0 & 0.25 & 0.3 & 0.3 & 0 & 0 & 0.5 & 1.65 \\
\hline 2014 & PL & 0.3 & 0 & 0.25 & 0.3 & 0.3 & 0 & 0 & 0.5 & 1.65 \\
\hline 2010 & RO & 0.3 & 0 & 0.25 & 0.3 & 0.3 & 0 & 0 & 0 & 1.15 \\
\hline 2011 & RO & 0.3 & 0 & 0.25 & 0.3 & 0.3 & 0 & 0 & 0 & 1.15 \\
\hline 2012 & RO & 0.3 & 0 & 0.25 & 0.3 & 0.3 & 0 & 0 & 0 & 1.15 \\
\hline 2013 & RO & 0.3 & 0 & 0.25 & 0.3 & 0 & 0 & 0.3 & 0.3 & 1.45 \\
\hline 2014 & $\mathrm{RO}$ & 0.3 & 0 & 0.25 & 0.3 & 0 & 0 & 0.3 & 0.3 & 1.45 \\
\hline 2010 & SK & 0 & 0 & 0.25 & 0.3 & 0 & 0 & 0 & 0 & 0.55 \\
\hline 2011 & SK & 0 & 0 & 0.25 & 0.3 & 0 & 0 & 0 & 0 & 0.55 \\
\hline 2012 & SK & 0.3 & 0 & 0.25 & 0.3 & 0 & 0 & 0 & 0.5 & 1.35 \\
\hline 2013 & SK & 0.3 & 0 & 0.25 & 0.3 & 0 & 0 & 0 & 0.5 & 1.35 \\
\hline 2014 & SK & 0.3 & 0 & 0.25 & 0.3 & 0 & 0 & 0.3 & 0.5 & 1.65 \\
\hline 2010 & SI & 0 & 0 & 0.25 & 0.3 & 0 & 0 & 0 & 0 & 0.55 \\
\hline 2011 & SI & 0 & 0 & 0.25 & 0.3 & 0 & 0 & 0 & 0 & 0.55 \\
\hline 2012 & SI & 0.3 & 0 & 0.25 & 0.3 & 0 & 0 & 0 & 0 & 0.85 \\
\hline 2013 & SI & 0.3 & 0 & 0.25 & 0.3 & 0 & 0 & 0 & 0 & 0.85 \\
\hline 2014 & SI & 0.3 & 0 & 0.25 & 0.3 & 0 & 0 & 0 & 0 & 0.85 \\
\hline 2010 & $\mathrm{HU}$ & 0.3 & 0 & 0.25 & 0.3 & 0.3 & 0 & 0.3 & 0 & 1.45 \\
\hline 2011 & $\mathrm{HU}$ & 0.3 & 0 & 0.25 & 0.3 & 0.3 & 0 & 0.3 & 0 & 1.45 \\
\hline 2012 & $\mathrm{HU}$ & 0.3 & 0 & 0.25 & 0.3 & 0 & 0 & 0 & 0 & 0.85 \\
\hline 2013 & HU & 0.3 & 0 & 0.25 & 0.3 & 0 & 0 & 0 & 0 & 0.85 \\
\hline 2014 & $\mathrm{HU}$ & 0.3 & 0 & 0.25 & 0.3 & 0 & 0 & 0 & 0 & 0.85 \\
\hline
\end{tabular}

Note: authors' computations according to validation of insights in the literature. Since the previous literature was discussed in the first part of our study shows that most of the time, there is the tendency to test the implications of some types of rules on fiscal sustainability, we consider that the framework requires not only a simple test of fiscal rules, but it is important to know the type of fiscal rule is in place and which is the legal basis of that rule.

The displayed results represent the qualitative approach of the last four years; the computed indicator was integrated in the quantitative framework for the entire analysis (2000-2014). We examined the type of fiscal rule in place (ER-expenditure rule, RRrevenue rule, BBR-budget balance rule, DR-debt rule) and then we established the approach of the legal basis of that rule (constitutional legal basis, international treaty legal basis, common law legal basis, coalition agreement, political commitment) (ERLBexpenditure rule legal basis, RRLB — revenue rule legal basis, BBRLB — budget balance rule legal basis, DR—debt rule legal basis).

In order to compute the convergence score of fiscal responsibility, we have established some logical premises:

1. We first found theoretical validation (Anderson et al. (2007)); Lienert et al. (2010) and Lienert (2013) [56-58], establish the significance of fiscal rules based on the legal basis and on the importance of those rules (in which case debt rules and expenditure rules are considered to be more effective. 
2. Second, we followed these literature insights, and we established different scores.

- $\quad$ The simple existence of fiscal rules in place $=0.25$ points.

- $\quad$ Debt rules and expenditure rule existence $=0.30$ points.

- $\quad$ Constitutional legal basis $=0.5$.

- International treaty legal basis $=0.4$.

- $\quad$ Common law legal basis $=0.3$.

- $\quad$ Coalition agreement $=0.2$.

- $\quad$ Political commitment $=0.1$.

The convergence score of fiscal responsibility was computed based on the sum of these two dimensions (the type of fiscal rule in place and legal basis) and highlights the variability between countries, thus it was appropriate to integrate the results in a quantitative framework (see Tables A1 and A2).

Appendix B. Unit Root Test Results for the Primary Balance and Primary Expenditure (2000-2014)

Table A2. Unit root test results for primary balance (2000-2014).

\begin{tabular}{|c|c|c|c|c|}
\hline Method & Statistics & $p$-Value * & Cross-Sections & Obs. \\
\hline \multicolumn{5}{|c|}{ Null: Unit root (assumes common unit root process) } \\
\hline $\begin{array}{l}\text { 382Levin, Lin \& } \\
\text { Chu t stat }\end{array}$ & -5.6384 & 0.0000 & 11 & 165 \\
\hline Breitung t-sta & -4.3477 & 0.0000 & 11 & 165 \\
\hline \multicolumn{5}{|c|}{ Null: Unit root (assumes individual unit root process) } \\
\hline $\begin{array}{l}\text { Im, Pesaran and } \\
\text { Shin W-stat }\end{array}$ & -3.0496 & 0.0000 & 11 & 165 \\
\hline $\begin{array}{l}\text { ADF-Fisher } \\
\text { Chi-square }\end{array}$ & 77.4373 & 0.0000 & 11 & 165 \\
\hline $\begin{array}{l}\text { PP-Fisher } \\
\text { Chi-square }\end{array}$ & 115.9818 & 0.0000 & 11 & 165 \\
\hline
\end{tabular}

Source: own calculations. ${ }^{*} p<0.1$.

Table A3. Unit root test results for primary expenditures (2000-2014).

\begin{tabular}{|c|c|c|c|c|}
\hline Method & Statistics & $p$-Value * & Cross-Sections & Obs. \\
\hline \multicolumn{5}{|c|}{ Null: Unit root (assumes common unit root process) } \\
\hline $\begin{array}{l}\text { Levin, Lin and } \\
\text { Chu t stat }\end{array}$ & -10.5450 & 0.0000 & 11 & 165 \\
\hline Breitung t-sta & -7.0873 & 0.0000 & 11 & 165 \\
\hline \multicolumn{5}{|c|}{ Null: Unit root (assumes individual unit root process) } \\
\hline $\begin{array}{l}\text { Im, Pesaran and } \\
\text { Shin W-stat }\end{array}$ & -3.7052 & 0.0000 & 11 & 165 \\
\hline $\begin{array}{l}\text { ADF-Fisher } \\
\text { Chi-square }\end{array}$ & 52.8480 & 0.0000 & 11 & 165 \\
\hline $\begin{array}{l}\text { PP-Fisher } \\
\text { Chi-square }\end{array}$ & 169.0001 & 0.0000 & 11 & 165 \\
\hline
\end{tabular}

\section{References}

1. Nerlich, C.; Reuter, W.H. The Design of National Fiscal Frameworks and Their Budgetary Impact. ECB Working Paper Series. 2013, p. 1588. Available online: https:/ /www.ecb.europa.eu/pub/pdf/scpwps/ecbwp1588.pdf (accessed on 13 February 2021). 
2. Franek, S.; Postula, M. Measuring the Strength of Fiscal Instruments and Their Effectiveness in Improving the Sustainability of Public Finances in European Union Countries; Materials and Studies; National Bank of Poland: Warsaw, Poland, 2019 ; p. 334.

3. Reuter, W.H. When and why do countries break their national fiscal rules? Eur. J. Political Econ. 2019, 57, 125-141. [CrossRef]

4. Badinger, H.; Reuter, W.H. The case for fiscal rules. Econ. Model. 2017, 60, 334-343. [CrossRef]

5. Wright, A.; Grenade, K.; Scott-Joseph, A. Fiscal Rules: Towards a New Paradigm for Fiscal Sustainability in Small States (No. IDB-WP-780); IDB Working Paper Series; IDB: Managua, Nicaragua, 2017; Available online: https://publications.iadb.org/ publications/english/document/Fiscal-Rules-Towards-a-New-Paradigm-for-Fiscal-Sustainability-in-Small-States.pdf (accessed on 13 March 2021).

6. Combes, J.-L.; Minea, A.; Sow, M. Is fiscal policy always counter- (pro-) cyclical? The role of public debt and fiscal rules. Econ. Model. 2017, 65, 138-146. [CrossRef]

7. Debrun, X.; Hauner, D.; Kumar, M.S. Independent fiscal agencies. J. Econ. Surv. 2009, 23, 44-81. [CrossRef]

8. Beetsma, R.; Debrun, X. Fiscal Councils: Rationale and Effectiveness. IMF Work. Pap. 2016, 16, 1. [CrossRef]

9. Alfaro, L.; Kanczuk, F. Fiscal Rules and Sovereign Default. Fisc. Rules Sover. Default 2017. [CrossRef]

10. Balke, N.; Ravn, M. Time Consistent Fiscal Policy in a Debt Crisis. CEPR Working Paper. 2016, p. 11646. Available online: http: //www.centreformacroeconomics.ac.uk/Discussion-Papers/2016/CFMDP2016-38-Paper.pdf (accessed on 23 February 2021).

11. Kamps, C.; Leiner-Killinger, N. Taking Stock of the Functioning of the EU Fiscal Rules and Options for Reform (August, 2019). ECB Occasional Paper No. 231. Available online: https:/ / ssrn.com/abstract=3445380 (accessed on 19 March 2021).

12. Beetsma, R.; Debrun, X.; Sloof, R. The Political Economy of Fiscal Transparency and Independent Fiscal Councils. IMF Work. Pap. 2017, 17. [CrossRef]

13. Beetsma, R.M.W.J.; Larch, M. EU Fiscal Rules: Further Reform or Better Implementation? SSRN Electron. J. 2019, 7-11. [CrossRef]

14. Debrun, X.; Kinda, T. Strengthening Post-Crisis Fiscal Credibility: Fiscal Councils on the Rise-A New Dataset. Fisc. Stud. 2017, 38, 667-700. [CrossRef]

15. Beuve, J.; Darvas, Z.; Delpeuch, S.; Martin, P.; Ragot, X. Simple Rules for Better Fiscal Policies in Europe. DICE Rep. 2019, 17, 12-16. Available online: https:/ / www.econstor.eu/bitstream/10419/216264/1/ifodice-2019-02-p12-16.pdf, (accessed on 17 December 2020).

16. Caselli, F.; Reynaud, J. Do fiscal rules cause better fiscal balances? A new instrumental variable strategy. Eur. J. Political Econ. 2020, 63, 101873. [CrossRef]

17. Guerguil, M.; Mandon, P.; Tapsoba, R. Flexible fiscal rules and countercyclical fiscal policy. J. Macroecon. 2017, 52, 189-220. [CrossRef]

18. Bergman, U.M.; Hutchison, M. Economic stabilization in the post-crisis world: Are fiscal rules the answer? J. Int. Money Financ. 2015, 52, 82-101. [CrossRef]

19. Debrun, X.; Moulin, L.; Turrini, A.; Ayuso-I-Casals, J.; Kumar, M.S. Tied to the mast? National fiscal rules in the European Union. Econ. Policy 2008, 23, 297-362. [CrossRef]

20. Krogstrup, S.; Wälti, S. Do fiscal rules cause budgetary outcomes? Public Choice 2008, 136, 123-138. [CrossRef]

21. Wyplosz, C. Fiscal Policy: Institutions versus Rules. Natl. Inst. Econ. Rev. 2005, 191, 64-78. [CrossRef]

22. Wierts, P. How Do Expenditure Rules Affect Fiscal Behaviour? SSRN Electron. J. 2012. [CrossRef]

23. Wyplosz, C. Fiscal Rules: Theoretical Issues and Historical Experiences; National Bureau of Economic Research: Cambridge, MA, USA, 2012; pp. 495-525.

24. Bova, E.; Carcenac, N.; Guerguil, M. Fiscal Rules and the Procyclicality of Fiscal Policy in the Developing World. IMF Work. Pap. 2014, 14, 1. [CrossRef]

25. Reuter, W.H. National numerical fiscal rules: Not complied with, but still effective? Eur. J. Political Econ. 2015, 39, 67-81. [CrossRef]

26. Bergman, U.M.; Hutchison, M.M.; Jensen, S.E.H. Promoting sustainable public finances in the European Union: The role of fiscal rules and government efficiency. Eur. J. Political Econ. 2016, 44, 1-19. [CrossRef]

27. Calmfors, L. The Role of Independent Fiscal Policy Institutions (28 February 2011). CESifo Working Paper Series No. 3367. Available online: https:/ / ssrn.com/abstract=1775797 (accessed on 23 January 2021).

28. Budina, N.; Schaechter, A.; Weber, A.; Kinda, T. Fiscal Rules in Response to the Crisis: Toward the "Next-Generation" Rules: A New Dataset. IMF Work. Pap. 2012, 12. [CrossRef]

29. Schick, A. Budgeting for fiscal space. OECD J. Budg. 2009, 9, 1-18. [CrossRef]

30. Beck, K.; Możdżeń, M. Institutional Determinants of Budgetary Expenditures. A BMA-Based Re-Evaluation of Contemporary Theories for OECD Countries. Sustainability 2020, 12, 4104. [CrossRef]

31. Goldfajn, I.; Guardia, E.R. Fiscal Rules and Debt Sustainability in Brazil. In Rules-Based Fiscal Policy in Emerging Markets; Springer: Berlin/Heidelberg, Germany, 2004; pp. 114-130.

32. Von Hagen, J. Fiscal Rules, Fiscal Institutions, and Fiscal Performance. 2002. Available online: https://www.esr.ie/ESR_papers/ vol33_3/Vol33_3vonHagen.pdf (accessed on 13 January 2021).

33. Deyal, Z.; Smets, L.; Ter-Minassian, T.; de Desarrollo, B.I.; Seminario, B.; Zegarra, M.A.; Gómez Reino, J.L. What Determines the Adoption of Fiscal Rules in Resource-Rich Developing Countries? An Empirical Investigation. 2020. Available online: https:/ / publications.iadb.org/publications/english/document/What_Determines_the_Adoption_of_Fiscal_Rules_in_ Resource-Rich_Developing_Countries_An_Empirical_Investigation.pdf (accessed on 13 February 2021).

34. Perotti, R. Fiscal Policy in Developing Countries: A Framework and Some Questions (1 September 2007). World Bank Policy Research Working Paper No. 4365. Available online: https:/ / ssrn.com/abstract=1016261 (accessed on 11 February 2021). 
35. Tapsoba, R. Do National Numerical Fiscal Rules really shape fiscal behaviours in developing countries? A treatment effect evaluation. Econ. Model. 2012, 29, 1356-1369. [CrossRef]

36. Drazen, A. Fiscal Rules from a Political Economy Perspective. In Rules-Based Fiscal Policy in Emerging Markets; Springer: Berlin/Heidelberg, Germany, 2004; pp. 15-29.

37. Afonso, A.; Jalles, J.T. Fiscal Rules and Government Financing Costs. Fisc. Stud. 2019, 40, 71-90. [CrossRef]

38. Sawadogo, P.N. Can fiscal rules improve financial market access for developing countries? J. Macroecon. 2020, 65, 103214. [CrossRef]

39. Blanchard, O.J.; Chouraqui, J.-C.; Hagemann, R.; Sartor, N. The Sustainability of Fiscal Policy: New Answers to an Old Question (March 1991). NBER Working Paper No. R1547. Available online: https:/ /ssrn.com/abstract=227461 (accessed on 21 February 2021).

40. Bohn, H. The Behavior of U. S. Public Debt and Deficits. Q. J. Econ. 1998, 113, 949-963. [CrossRef]

41. Bohn, H. The Sustainability of Fiscal Policy in the United States. In Sustainability of Public Debt; Neck, R., Sturm, J., Eds.; MIT Press: Cambridge, MA, USA, 2008; pp. 15-49.

42. Ghosh, A.R.; Kim, J.I.; Mendoza, E.G.; Ostry, J.D.; Qureshi, M.S. Fiscal Fatigue, Fiscal Space and Debt Sustainability in Advanced Economies. Econ. J. 2013, 123, F4-F30. [CrossRef]

43. Daniel, B.C.; Shiamptanis, C. Fiscal risk in a monetary union. Eur. Econ. Rev. 2012, 56, 1289-1309. [CrossRef]

44. Afonso, A.; Jalles, J.T. Do fiscal rules matter for growth? Appl. Econ. Lett. 2013, 20, 34-40. [CrossRef]

45. Afonso, A.; Hauptmeier, S. Fiscal Behaviour in the European Union: Rules, Fiscal Decentralization and Government Indebtedness (7 May 2009). ECB Working Paper No. 1054. Available online: https://ssrn.com/abstract=1399284 (accessed on 20 January 2021).

46. Bruno, G.S. Approximating the bias of the LSDV estimator for dynamic unbalanced panel data models. Econ. Lett. 2005, 87, 361-366. [CrossRef]

47. Fomby, T.B.; Carter Hill, R. Nonstationary Panels, Panel Cointegration, and Dynamic Panels; Badi, H.B., Ed.; JAI: Greenwich, CT, USA, 2000.

48. Bergman, U.M.; Hutchison, M.M. Fiscal Procyclicality in Developing Economies: Role of Fiscal Rules, Institutions and Economic Conditions. 2018. Available online: https://www.researchgate.net/profile/U_Bergman/publication/325820923_Fiscal_ Procyclicality_in_Developing_Economics_The_Role_of_Fiscal_Rules_Institutions_and_Economic_Conditions/links/5b27a3 e30f7e9be8bdaf62a2/Fiscal-Procyclicality-in-Developing-Economics-The-Role-of-Fiscal-Rules-Institutions-and-EconomicConditions.pdf/ (accessed on 13 October 2020).

49. Eyraud, L.; Debrun, X.; Hodge, A.; Lledo, V.; Pattillo, C. Second-Generation Fiscal Rules: Balancing Simplicity, Flexibility, and Enforceability. Staff. Discuss. Notes 2018, 18. [CrossRef]

50. Afonso, A.; Zartaloudis, S.; Papadopoulos, Y. How party linkages shape austerity politics: Clientelism and fiscal adjustment in Greece and Portugal during the eurozone crisis. J. Eur. Public Policy 2015, 22, 315-334. [CrossRef]

51. Sacchi, A.; Salotti, S. The impact of national fiscal rules on the stabilisation function of fiscal policy. Eur. J. Political Econ. 2015, 37, 1-20. [CrossRef]

52. Buti, M.; Martins, J.N.; Turrini, A. From Deficits to Debt and Back: Political Incentives under Numerical Fiscal Rules. CESifo Econ. Stud. 2007, 53, 115-152. [CrossRef]

53. Halac, M.; Yared, P. Fiscal Rules and Discretion in a World Economy. SSRN Electron. J. 2015, 108, 2305-2334. [CrossRef]

54. Constitutional Court of Romania. Decision no. 155/6 May 2020. Available online: http://legislatie.just.ro/Public/ DetaliiDocumentAfis/211744 (accessed on 23 February 2021).

55. Constitutional Court of Romania. Decision no. 127/6 March 2019. Available online: http://legislatie.just.ro/Public/ DetaliiDocument/226553 (accessed on 23 February 2021).

56. Anderson, B.; Minarik, J.J. Design Choices for Fiscal Policy Rules. SSRN Electron. J. 2007. [CrossRef]

57. Lienert, I.; Fainboim, I. Reforming Budget System Laws. IMF Technical Notes and Manuals No. 1. 2010. Available online: https:/ / www.imf.org/en/Publications/TNM/Issues/2016/12/31/Reforming-Budget-System-Laws-23540 (accessed on 13 January 2021).

58. Lienert, I. Fiscal responsibility laws: Are they needed? J. Int. Commer. Econ. Policy 2013, 4, 1350017. [CrossRef] 